\title{
Adult Papillary Meningioma
}

National Cancer Institute

\section{Source}

National Cancer Institute. Adult Papillary Meningioma. NCI Thesaurus. Code C8293.

A papillary mening ioma occurring in adults. 